\title{
Features of cadastral registration of real estate objects using 3D technologies
}

\author{
Oleg Tsvetkov ${ }^{1, *}$, Ekaterina Vasileva $^{1}$ and Kirill Kulakov ${ }^{2}$ \\ ${ }^{1}$ Peter the Great St. Petersburg Polytechnic University, 29, Politekhnicheskaya str., 195251, St. \\ Petersburg, Russia \\ ${ }^{2}$ Moscow State University of Civil Engineering, 26, Yaroslavskoye shosse, Moscow, 129337, Russia
}

\begin{abstract}
The paper deals with the analysis and collection of information for state cadastral registration of real estate objects with certain design features. Previously, these design and technological features were not reflected in the cadastral documentation and quite often became a source of contradictions between stakeholders. Certain technical issues were settled only after going to court and pronouncing of a judgment. A list of problems that a cadastral engineer may encounter when collecting and analyzing data on an object in the matter of cadastral registering various types of underground structures, multi-level, multi-tiered objects and buildings of different heights for various purposes and profiles, as well as objects equipped with hidden niches and openings is given. The issues related to the state cadastral registration of casting structures are considered in terms of the individual characteristics of this process. The use of 3D cadastre technology is proposed as a real tool for solving the above issues. The positive experience of this practice in foreign countries is described. National features of the application of these technologies in the Russian Federation are given.
\end{abstract}

\section{Problem statement}

Nowadays, 3D technologies are actively and universally used in solving many economic issues all over the world. In Russia, this technology is also used in design, construction, and in addition, work is underway to introduce $3 \mathrm{D}$ technologies into the system of cadastral registration of real estate objects. It should be noted that domestic scientists rely on the works of their foreign colleagues from Germany, Sweden, Norway and the United States, since this system has already been developed in these countries and functions in open access.

In 2004, a scientist from the Netherlands, Jantine Esther Stoter, laid the foundation for the classification of 3D inventory species. In his work [1], he considered three types of 3D cadastre, from the simplest - the creation of a geoinformation base of objects, to a more complex system - the complete transfer of all objects and their attributes into a volumetric format. Today in Europe, the ideological inspirers and devotees studying the 3D cadastre system are considered: Tor Valstad, Peter J.M. van Oosterom, Hendrik D. Ploeger, Paul van

\footnotetext{
*Corresponding author: tsvetol778@mail.ru
} 
der Molen, etc. Unfortunately, the works of these authors were not published in Russia and were not translated into Russian, which, of course, slowed down the development of this system in our country.

At the same time, Dutch scientists and engineers, together with specialists from the Federal Service for State Registration, Cadastre and Cartography (hereinafter - Rosreestr), have been working since 2011 to create a proto-type 3D cadastre for its subsequent implementation throughout the Russian Federation. The Nizhny Novgorod region was selected as a pilot region. In September 2020, the head of Rosreestr announced that laser scanning technology would be tested this year in one of the regions [2].

Many Russian authors and developers publish their works on the use of 3D technologies in cadastral accounting in Russia. So, in their works, N.V. Gavryushina, V.L. Belyaev, V.M. Romanov, T.V. Nikolaeva, V.N. Nikitin, I.I. Snezhko et al. give theoretical and practical aspects of the implementation of a three-dimensional representation of objects of cadastral registration. In parallel, these scientists identify the main problems of Russian legislation and the accounting system, which do not yet allow the full use of this technology.

It is already possible to say with confidence that using world experience in creating a three-dimensional cadastral registration system, Russia can make a qualitative step forward in this direction in the near future.

Today, there are certain problems in the real estate cadastre associated with accounting for underground structures, objects with variable height. In general, such characteristics as height, depth, and volume are also not taken into account in the USRN. All real estate objects are determined by entering only the plane coordinates of the object's boundaries into the USRN, which allows determining only their area. In addition, the current accounting system for real estate objects does not allow clearly identifying pipelines, power lines and high-rise buildings. At this stage, it is almost impossible to take into account such objects as bridges, metro tunnels, road junctions, overpasses and other complex objects.

But it is the accounting of objects located underground (metro, transport tunnels and pipelines) that gives rise to many court questions and disputes. The issue of accounting for underground garages in cities is extremely acute. It is also worth noting that $3 \mathrm{D}$ cadastre will allow displaying relief, green spaces and other objects located above and below the ground.

In this regard, the question arises of the development and implementation of a 3D real estate accounting system. It should be understood that technological changes must be supported by a regulatory framework, which will also undergo a certain correction [3].

\section{Registration of underground structures}

The structure, according to clause 1 of article 130 of the Civil Code of the Russian Federation [4], refers to real estate objects, which is caused by a feature characteristic of all real estate objects, namely, a strong connection with the ground and the impossibility of moving without causing disproportionate damage to it. However, the Civil Code does not give a clear definition of the structure. The term "structure" is defined in Federal Law No. 384 - FZ [5], according to which a structure is the result of construction, which is a volumetric, planar or linear construction system that has a surface, aboveground and (or) underground parts, consisting of load-bearing and, in some cases, enclosing building structures, and designed to perform production processes of various types, storage of products, temporary stay of people, movement of people and goods. This definition is abstract and does not contain clear characteristics by which a structure can be defined and its type can be specified, for example, structures used in the energy, gas industry or communications. 
Such uncertainty significantly affects the possibility of including structures in civil commerce, since the absence of a legitimate definition enshrined in the established procedure often generates contradictions in law enforcement and judicial practice.

According to clause 34 of the requirements for the preparation of a technical plan and the composition of the information contained therein [6], if a building, structure, object of construction in progress has ground, aboveground and (or) underground structural elements, the outline of such a building, structure, object of construction in progress on a land plot is defined as a set of contours formed by the projection of the outer boundaries of ground, aboveground and (or) underground enclosing structures of such a building, structure, object of construction in progress on a horizontal plane passing at the level of adjoining such a building, structure, object of construction in progress to the ground surface.

If a building or structure is completely located underground (Fig. 1), then the contour of such a real estate object is formed by the projection of the outer boundaries of the enclosing structures of such a building, structure, or object of construction in progress onto a horizontal plane passing at the level of the ground surface. Therefore, the main problem that can be encountered when registering an underground structure is the indication of the cadastral numbers of land plots within which the structure is located.

Nowadays, there are already certain difficulties in registering underground parking lots and parking spaces, since it is impossible in cadastral practice to register part of the premises as an independent real estate object.

To register the ownership of a separate parking space located in the parking building or in the underground parking of a residential building, it is necessary that it meets the requirements of federal legislation for the premises, namely, it should have a fence, which is not always possible. The way out in this situation is to register the right to a share in the common shared ownership of the parking lot.

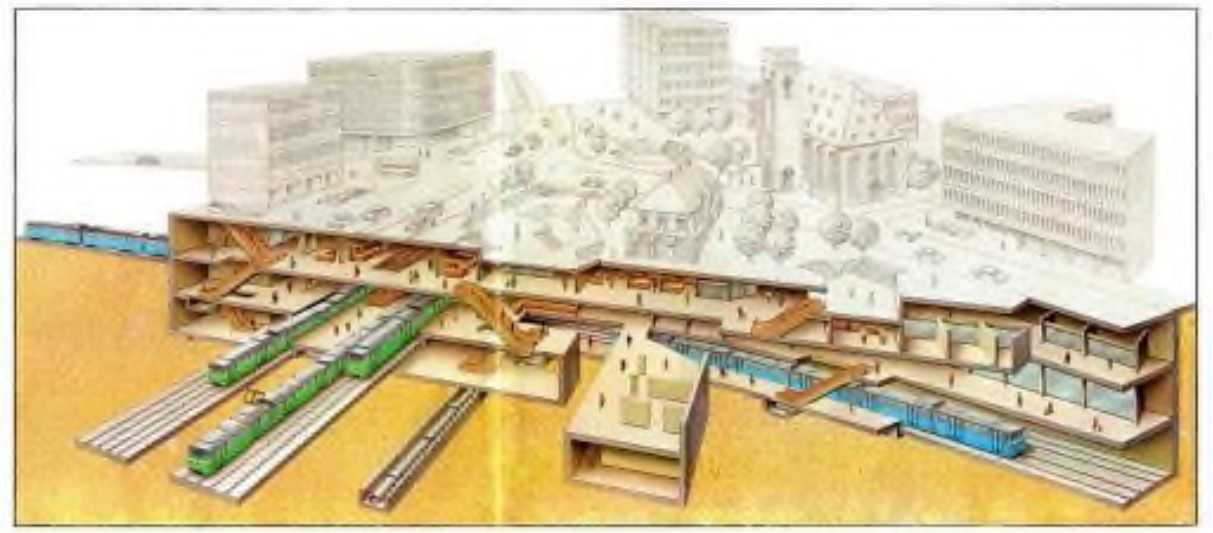

Fig. 1. Underground structures.

For a cadastral engineer, in this case, the question of the actual definition of the contour of an underground facility arises. This problem can be completely solved now using the 3D cadastral accounting system $[7,8]$. 


\section{Registration of rooms of different heights and multi-level objects}

Living quarters with ceilings of different heights are now more common. Ceilings of different heights are a feature of apartments on the top floors, penthouses or attics. Most often, such apartments can be found in the historical part of cities.

During cadastral registration of such apartments, their volume and ceiling height are not taken into account, since according to Order No. 90 [9], the lengths of the sides of the premises, and therefore the area of the premises, are determined at a height of $1.1-1.3$ meters. Therefore, in taxation, the height of the ceilings does not matter. Thus, the cadastral engineer, when drawing up the technical plan of the premises, does not indicate its height anywhere, and the owner, when receiving an extract from the USRN, receives only a flat image of the apartment.

Also, one of the problems is the cadastral registration of multilevel objects with overhanging parts and console elements. On the one hand, balconies, terraces and loggias can act as overhanging parts, on the other hand, for individual objects, the ground contour does not completely coincide with the above-surface one (multilevel objects) (Fig. 2).
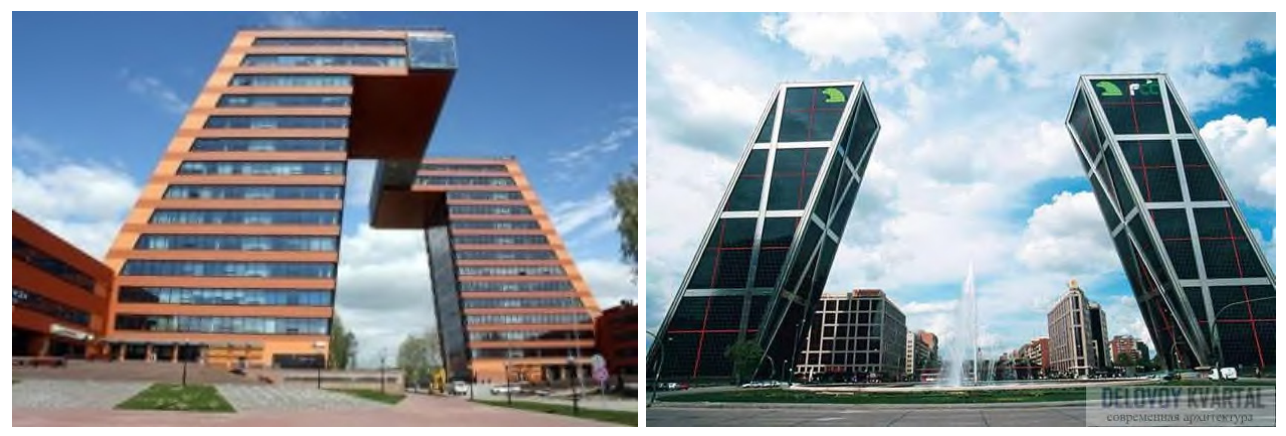

Fig. 2. An example of multilevel objects (Technopark, Novosibirsk and Gates of Europe Skyscrapers, Madrid).

It was mentioned above that such objects should be considered as multi-contour. But when determining flat coordinates by traditional geodetic methods, discrepancies may arise due to the lack of correspondence between the boundaries of the ground and above-ground contours (when the object's contours are beyond the boundaries of the allotted land plot), which may serve as a refusal to register for cadastral registration [10-12.

\section{Registration of rooms with hidden niches and openings Registration of linear structures}

As noted earlier, the area of the premises is determined at a height of 1.1-1.3 meters. Also, in accordance with Order No. 90 of the Ministry of Economic Development of the Russian Federation of 01.03.2016, the area of living quarters includes niche areas, but only with a height of more than 2 meters. This means that niches with a height of less than 2 meters are not reflected in the floor plans, which can cause a lot of controversy when buying and selling or redeveloping premises (Fig. 3).

Nowadays, there is no such concept as a linear object in Russian legislation. This concept is not disclosed in any regulatory legal act. 
In the Urban Planning Code of the Russian Federation and in the Federal Law "On the transfer of lands or land plots from one category to another", linear objects include power lines, communication lines, railway lines, highways, pipelines and other similar structures.
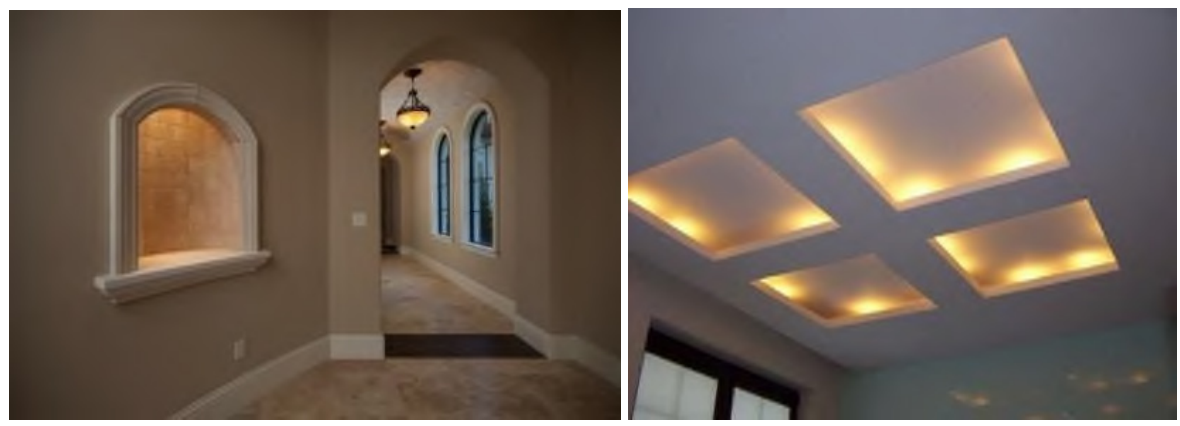

Fig. 3. Niche examples.

Typically, linear objects are characterized by the prevalence of length over width. This group of objects includes such objects of capital construction as: highways, railways, pipelines, tunnels, bridges, metro, etc. They differ in their scale, sometimes they can be located on the territory of several regions of the country, so there is no doubt that such objects belong to linear ones.

When registering for cadastral registration, linear objects are shown with a polyline. This means that when registering power lines, the supports are not displayed in any way, just as their height is not taken into account and at what height the wires themselves are located [10].

\section{Conclusion. New technologies and their possibilities in expanding the information base of real estate objects}

Since January 1, 2017, paragraphs have been added to the Order N 953 of December 18, 2015 , which regulate that the cadastral engineer can include a 3D model of the object in the annex to the technical plan at the request of the customer. This model should be built on a 1:1 scale with a coordinate reference to the state geodetic network or the reference boundary network, which were used in the performance of cadastral works. This model must necessarily include information about the depth and height of all structural elements [6].

The reform of the cadastral registration system will lead to a number of new areas of work with the consumer. The customer will be able to "see" in advance where the apartment is located, evaluate the view from the window and insolation. Nowadays, many construction companies are using unmanned aerial vehicles for shooting in order to more clearly demonstrate to the customer the place where the house and the apartment itself are located, but, of course, this is a good marketing ploy. Thus, with the help of 3D technology, the customer will be able to objectively assess not only the actual characteristics of the apartment itself, but also the entire volume of space around the house and on the staircase. Consequently, the introduction of 3D cadastre technologies will allow solving the issues of determining and clarifying both the cadastral value and the market value.

From all of the above it can be stated that 3D cadastre technologies can evolve to a cadastre made entirely in $3 \mathrm{D}$, which is currently difficult to achieve in the Russian Federation. Also, it is possible to use certain information in 3D format in the already existing cadastral registration system. 


\section{References}

1. Rosreestr will test $3 D$ laser scanning technology for cadastral works (Tacc) https://tass.ru/nedvizhimost/9461981

2. E.A. Pavlova, Young scientist 8, 40-42 (2012) https://moluch.ru/archive/43/5236/

3. Civil Code of the Russian Federation (part one) N 51-FZ of 30.11 .1994 (2019)

4. Federal Law "Technical Regulations on the Safety of Buildings and Structures" $N$ 384-FZ (2009)

5. Order of the Ministry of Economic Development of the Russian Federation N 953 of December 18 (2015)

6. V.L. Belyaev, V.M. Romanov, Property relations in the Russian Federation 1(148) (2014) https://cyberleninka.ru/article/n/opyt-i-perspektivy-primeneniya-3d-kadastrapri-upravlenii-gradostroitelnym-razvitiem-podzemnogo-prostranstva

7. N.V. Gavryushina, Interexpo Geo-Siberia 2 https://cyberleninka.ru/article/n/nekotorye-voprosy-gosudarstvennogo-kadastrovogoucheta-podzemnyh-sooruzheniy (access date: 22.04.2020).

8. Order of the Ministry of Economic Development of the Russian Federation No. 90 of March 1 (2016)

9. Ognjenovic, S., Donceva, R., Vatin, N. DProcedia Engineering. 2015. 117(1). Pp. 551558. DOI:10.1016/j.proeng.2015.08.212.

10. Ognjenovic, S., Ristov, R., Vatin, N. Procedia Engineering. 2015. 117(1). Pp. 568-573. DOI:10.1016/j.proeng.2015.08.215.

11. Ognjenović, S., Zafirovski, Z., Vatin, N. Procedia Engineering. 2015. 117(1). Pp. 574579. DOI:10.1016/j.proeng.2015.08.216.

12. R.M. Alaguzov, Interexpo GEO-Siberia $\mathbf{8} \quad$ (2018) https://cyberleninka.ru/article/n/obosnovanie-neobhodimosti-vvedeniya-dopolnitelnyhharakteristik-pri-postanovke-lineynyh-obektov-na-kadastrovyy-uchet 